\title{
SARS-CoV-2 seroepidemiological study in healthcare workers and discordant results using seven different diagnostic methods
}

\author{
Elizabeth-Barbara Tatsi ${ }^{1}$ D $\cdot$ Charilaos Dellis ${ }^{1} \cdot$ Evangelia Petridou $^{2} \cdot$ Kirkira Banou $^{2} \cdot$ Levantia Zachariadou $^{2}$. \\ Vassiliki Syriopoulou ${ }^{1} \cdot$ Athanasios Michos $^{1}$
}

Received: 30 April 2021 / Accepted: 25 June 2021 / Published online: 5 July 2021

(c) Springer-Verlag GmbH Germany, part of Springer Nature 2021

\begin{abstract}
The aim of the study was to access the SARS-CoV-2 antibody seroprevalence in healthcare workers (HCWs) of a tertiary pediatric hospital after the first wave of the pandemic and to compare the results among seven commercially available antibody detection assays, including chemiluminescence (CMIA), electroluminescence (ECLIA), Enzyme-Linked Immunosorbent Assay (ELISA), and rapid immunochromatography (RIC). SARS-CoV-2 antibody detection was performed in serum samples of $1216 \mathrm{HCWs}$, using a reference CMIA assay and 8/1216 (0.66\%) were detected positive. Positive serum samples were further tested with other assays; however, only one sample was positive by all tests. The rest 7 cases were negative with ECLIA and ELISA and gave discordant results with RIC test. Six months later, new serum samples of seropositive HCWs were analyzed with the same 7 tests, with inconsistent results again. Identification of reliable SARS-CoV-2 antibody tests is important to determine the actual number of past infections, the duration of antibodies, and guide public health decisions.
\end{abstract}

Keywords SARS-CoV-2 $\cdot$ COVID-19 $\cdot$ Serology $\cdot$ Antibody $\cdot$ Comparison $\cdot$ Immunity

\section{Introduction}

On 2019, a new severe acute respiratory syndrome coronavirus $(\mathrm{CoV})$ was isolated in Wuhan, China, identified as SARS-CoV-2 in January 2020. The World Health Organization (WHO) declared SARS-CoV-2 disease (COVID-19) as a public health emergency of international concern [1].

The SARS-CoV-2 is the seventh known coronavirus and the third $\mathrm{CoV}$ associated with severe respiratory syndromes. As a member of CoVs, SARS-CoV-2 is an enveloped, positive-sense single-stranded RNA virus that is enabled to infect human and other mammals. Based on genomic data, the most probable natural host of SARS-CoV-2 is the bat which was likely transmitted to humans through an intermediate

Elizabeth-Barbara Tatsi

etatsi@med.uoa.gr

1 First Department of Pediatrics, Infectious Diseases and Chemotherapy Research Laboratory, Medical School, National and Kapodistrian University of Athens, "Aghia Sophia" Children's Hospital, Thivon and Papadiamantopoulou, Athens 11527, Greece

2 Department of Microbiology, "Aghia Sophia" Children's Hospital, Athens 11527, Greece host, like pangolin. The virus infects the nasal and bronchial epithelial cells and pneumocytes through binding of the viral glycoprotein spike (S) to the human receptor angiotensinconverting enzyme 2 (ACE2) $[2,3]$.

The human-to-human transmission mainly happens through droplets during talking, coughing and sneezing, touching an infected surface as well as through aerosols. An infected person could transmit the virus whether is presymptomatic, symptomatic or asymptomatic [3, 4]. The most common clinical features are fever, cough, dyspnea and may also include anosmia, dysgeusia, headache, gastrointestinal symptoms and skin lesions [5-7]. Elderly and people with comorbidities are at increased risk for a severe COVID-19 infection with worse outcome [5].

In Greece, coronavirus protection measures were taken immediately resulting in a particularly low incidence rate in the first wave of the pandemic (until 2 July 2020: $3,500 / 10,720,000 ; 0.033 \%$ ); however, this rate may be underestimated due to the asymptomatic cases (https://eody. gov.gr/wp-content/uploads/2020/07/covid-gr-daily-report20200702.pdf).

Healthcare workers (HCWs) are also at increased risk for COVID-19 infection, due to the frontline nature of their 
work and higher seroprevalence has been detected compared to the general population [8-10].

Testing for SARS-CoV-2 specific antibodies in serum has become an important tool for documenting past infections and determining the prevalence of COVID-19 in population serosurveys [11-13]. While these assays are increasingly applied in SARS-CoV-2 seroprevalence studies, there are limitations in the interpretation and application of qualitative antibody tests for clinical and public health decision-making $[12,14]$. Depending on the method, there is a possibility of false-positive results from cross-reactivity with other coronaviruses or autoantibodies or for false-negative results if there is testing early during COVID-19 infection [15]. There is currently little standardization of assays designed to measure antibodies to SARS-CoV-2, resulting in assays of varying sensitivity and specificity and a consequent difficulty in comparing seroprevalence rates between studies and/or countries $[12,16]$.

The aim of the present study was to detect the SARSCoV-2 seropositivity rate in HCWs of the largest pediatric hospital of Greece after the first wave of SARS-CoV-2 pandemics, using an FDA-approved assay and to compare the positive results with 6 additional commercially available anti-SARS-CoV-2 antibody detection tests.

\section{Materials and methods}

\section{Study design and participants}

A prospective cohort study was conducted at "Aghia Sophia" Children's Hospital, Athens, Greece, in June and December 2020 , to check the seropositivity of healthcare personnel for SARS-CoV-2 infection. This is the largest tertiary pediatric hospital in Greece with almost 1400 HCWs. The HCWs cohort of the study included medical professionals (medical doctors, nurses, biologists, technicians) and nonmedical personnel of the hospital (administrative staff, cleaners, etc.), who voluntarily were checked for their SARS-CoV-2 antibody status.

The initial SARS-CoV-2 antibody testing was performed in June 2020 and HCWs with serum samples positive for SARS-CoV-2 antibodies in the initial screening were further tested with 6 additional anti-SARS-CoV-2 antibody detection assays in June and December 2020.

Demographic, travel history and medical history characteristics of anti-SARS-CoV-2 positive people were also collected.

\section{Laboratory assays}

Healthcare personnel were initially screened for SARSCoV-2 IgG antibodies using the selected from public health authorities Architect ${ }^{\circledR}$ SARS-CoV-2 IgG (Abbott, Chicago, IL, USA) assay on an ARCHITECT i2000SR instrument. This test is a Chemiluminescent Microparticle Immunoassay (CMIA), with a cutoff index (COI) value of 1.4.

The positive serum samples were further tested for anti-SARS-CoV-2 antibodies using the following 6 different assays: one electrochemiluminescence Immunoassay (ECLIA; Elecsys® Anti-SARS-CoV-2 (Roche, Basel, Switzerland) on a cobas e 411 analyzer, one Enzyme-Linked Immunosorbent Assay (ELISA; Anti-SARS-CoV-2 ELISA IgG (EUROIMMUN, Lubeck, Germany) and four Rapid Immunochromatographic (RIC) tests. All antibody tests were conducted according to the manufacturer's instructions. Performance details regarding the characteristics of anti-SARS-CoV-2 antibody tests used in this study are presented in Supplementary Table 1.

\section{Statistical analysis}

Statistical analysis was performed using the SPSS v. 25 software (IBM Corp.) and $p$ value $<0.05$ was considered statistically significant. The data are expressed as percentages (\%), mean and standard deviation (SD) or median and interquartile range (IQR) depending on the variable and the normality.

\section{Ethical issues}

Our study was conducted in accordance with the Declaration of Helsinki and the study protocol was approved by the scientific and bioethics committee of "Aghia Sophia" Children's Hospital (protocol code No: 25609). Written informed consent was obtained from the participants.

\section{Results}

SARS-CoV-2 IgG antibody detection was prospectively performed in serum samples from $1216 \mathrm{HCWs}$. Of them, 955 were women $(78.5 \%)$ and $261(21.5 \%)$ men, with mean age ( \pm SD) (years): $46.9 \pm 10.7$ (range: $23-76$ years). From HCWs, 364 (29.9\%) were medical doctors, 371 (30.5\%) were nurses, and 481 (39.6\%) were other hospital workers.

Initial testing for SARS-CoV-2 IgG antibody with the Abbott Architect ${ }^{\circledR}$ SARS-CoV-2 IgG assay in June 2020 detected eight positive samples $(8 / 1216,0.66 \%)$. The epidemiological and medical history characteristics of the antiSARS-CoV-2 positive HCWs are presented in Table 1. Six seropositive HCWs were administrative staff of the hospital, one was medical doctor and one was nurse. Their median age of seropositive HCWs was 42 years (IQR: 35.25-49.5) and $75 \%(6 / 8)$ were female. Three of them reported mild symptoms of infection in March 2020 without any further 


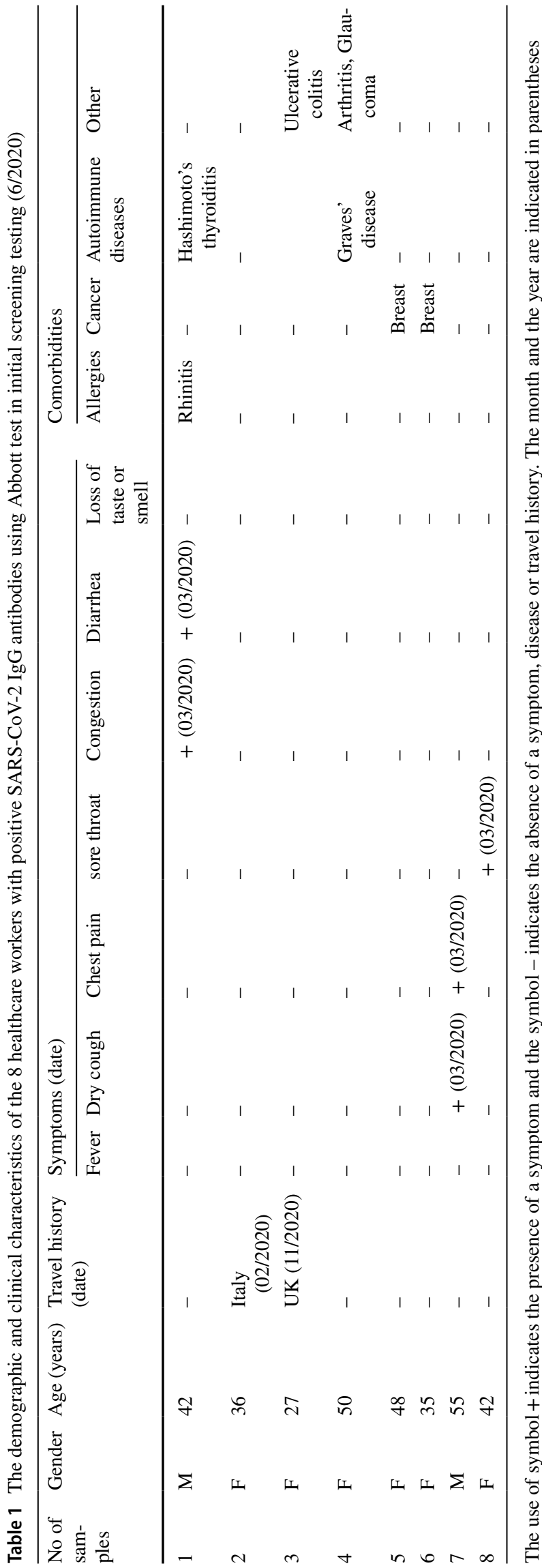

SARS-CoV-2 molecular testing, 5/8 had comorbidities, and two had travel history (Table 1).

Further testing of the same 8 positive serum samples, using six additional different antibody assays showed variable results (Table 2). Only the result of one HCW (\#1) $(1 / 8,12.5 \%)$ was verified by all methods, while the other 7 cases gave discordant results (Table 2). For the rest of the personnel, ECLIA and ELISA methods were negative and there was agreement of the Abbott Architect ${ }^{\circledR}$ for one person (\#5) with 3 rapid assays and in three persons (\#2,\#3,\#8) with one rapid assay. In the 6-month follow-up, the person (\#1) who was positive in all assays in the initial screening, became negative with the Abbott Architect ${ }^{\circledR}$ but continued positive with all other assays. The Abbott Architect ${ }^{\circledR}$ assay remained positive in $6 / 8$ persons and there was agreement with one rapid assay for 4 persons (\#2,\#3,\#5, \#8) (Table 2).

\section{Discussion}

In the present study, we report the seroprevalence of SARSCoV-2 in HCWs including medical and nonmedical personnel of the major tertiary pediatric hospital of Greece, after the first epidemic wave. However, when we further tested the positive samples after the initial screening with different antibody detection methods, we found contradictory results.

The present study compares 4 different techniques for antibody detection (ELISA, ECLIA, CMIA and RICs) and has a 6-month follow-up. Additionally, we determined the percentage of the seropositive SARS-CoV-2 pediatric HCWs after the first wave of the pandemic in our region.

As COVID-19 is asymptomatic in at least 50\% of people depending on age, serological studies are important to estimate the burden of disease in the community, to determine potential herd immunity against the infectious agent, and to guide public health measures and vaccination policies $[13,17]$. Nevertheless, the lack of well-standardized SARS$\mathrm{CoV}-2$ quantitative IgG assays precludes the comparison of results from published studies [12].

The initial screening in the present study detected a low seroprevalence $(0.66 \%)$, which is lower from what is reported in HCWs from other European pediatric hospitals, such as in Spain (4\% using the RIC assay Virusee ${ }^{\odot}$; Genobio Pharmaceutical, Shanghai, China) or Italy (5.13\% using the Euroimmun SARS-CoV-2 ELISA like in our study) $[18,19]$. In a recent study that compared seroprevalence in HCWs in Pediatric Healthcare facilities from eight different countries using the EDI New Coronavirus COVID-19 IgG against $\mathrm{N}$ protein ELISA (Epitope diagnostics, USA) and a multiplexed assay for IgG against $\mathrm{N}$ protein, receptor binding domain of S1 subunit and trimeric spike antigen (MSD SARS-Coronavirus Plate 1, Rockville, MD,USA), a significant diversity was noted with higher in London $(16,93 \%)$ and 
Table 2 The results of SARS-CoV-2 antibodies (Abs) detection employing 7 different tests in 8 seropositive healthcare workers after initial screening with the Abbott test in 2 different time points, 6 months apart. (6/2020 and 12/2020)

\begin{tabular}{|c|c|c|c|c|c|c|c|c|c|c|c|c|c|c|c|}
\hline \multirow[t]{2}{*}{$\begin{array}{l}\text { Methods } \\
\text { Measures }\end{array}$} & & \multicolumn{2}{|c|}{$\begin{array}{l}\text { Abbott Architect } \\
\text { SARS-CoV-2 IgG } \\
(\geq 1.4 \mathrm{COI})\end{array}$} & \multicolumn{2}{|c|}{$\begin{array}{l}\text { Roche Elecsys Anti-SARS- } \\
\text { CoV-2 ( } \geq 1 \text { COI) }\end{array}$} & \multicolumn{2}{|c|}{$\begin{array}{l}\text { EUROIM- } \\
\text { MUN Anti- } \\
\text { SARS- } \\
\text { CoV-2 } \\
\text { ELISA } \\
\text { (IgG) }\end{array}$} & \multicolumn{2}{|c|}{$\begin{array}{l}\text { Cellex } \\
\text { qSARS- } \\
\text { CoV-2 IgG/ } \\
\text { IgM Test }\end{array}$} & \multicolumn{2}{|c|}{$\begin{array}{l}\text { Dyon- } \\
\text { Covid19 } \\
\text { IgG/IgM } \\
\text { Test }\end{array}$} & \multicolumn{2}{|c|}{$\begin{array}{l}\text { NADAL } \\
\text { COVID-19 } \\
\text { IgG/IgM } \\
\text { Test }\end{array}$} & \multicolumn{2}{|c|}{$\begin{array}{l}\text { STAND- } \\
\text { ARD Q } \\
\text { COVID- } \\
19 \text { IgM/ } \\
\text { IgG } \\
\text { Combo }\end{array}$} \\
\hline & & $1^{\text {st }}$ & $2^{\text {nd }}$ & $1^{\text {st }}$ & $2^{\text {nd }}$ & $1^{\text {st }}$ & $2^{\text {nd }}$ & $1^{\text {st }}$ & $2^{\text {nd }}$ & $1^{\text {st }}$ & $2^{\text {nd }}$ & $1^{\mathrm{st}}$ & $2^{\text {nd }}$ & $1^{\text {st }}$ & $2^{\text {nd }}$ \\
\hline \multirow[t]{8}{*}{ No of Samples } & 1 & $2.50(+)$ & $0.55(-)$ & $27.71(+)$ & $4.750(+)$ & + & + & + & + & + & + & + & + & + & + \\
\hline & 2 & $3.90(+)$ & $3.14(+)$ & $0.078(-)$ & $0.104(-)$ & - & - & - & - & + & + & - & - & - & - \\
\hline & 3 & $1.70(+)$ & $1.56(+)$ & $0.078(-)$ & $0.093(-)$ & - & - & - & - & + & + & - & - & - & - \\
\hline & 4 & $5.62(+)$ & $4.59(+)$ & $0.088(-)$ & $0.097(-)$ & - & - & - & - & - & - & - & - & - & - \\
\hline & 5 & $2.02(+)$ & $1.53(+)$ & $0.085(-)$ & $0.100(-)$ & - & - & + & - & + & + & - & - & + & - \\
\hline & 6 & $1.46(+)$ & $0.86(-)$ & $0.084(-)$ & $0.099(-)$ & - & - & - & - & - & - & - & - & - & - \\
\hline & 7 & $2.40(+)$ & $1.95(+)$ & $0.075(-)$ & $0.100(-)$ & - & - & - & - & - & - & - & - & - & - \\
\hline & 8 & $2.52(+)$ & $2.02(+)$ & $0.089(-)$ & $0.112(-)$ & - & - & - & - & + & + & - & - & - & - \\
\hline
\end{tabular}

The use of symbol+indicates the presence of SARS-CoV-2 IgG antibodies and the symbol - indicates the absence of SARS-CoV-2 IgM and IgG antibodies; COI: Cutoff Index

Cape Town (10.36\%), in contrast to Austrian, Estonian, and Latvian cohorts, where there was no positive HCWs [16]. Greece had the fewest recorded cases among these countries; thus, these differences in seropositivity may reflect the seroprevalence of the general population of each country.

Studies reporting the seropositivity of HCWs from children's hospitals detect a much lower incidence compared with adults' hospitals at the same period, probably because of the lower burden of COVID-19 infection in children and exposure of personnel. In Greece, at the same region and period, the seropositivity in adult's hospitals was double (1.26\%) [20]. Areas that faced a high surge of COVID-19 infection during the first epidemic wave detected much higher seroprevalence like in New York (27\%), which was comparable to $24.4 \%$ observed in a cross-sectional study from UK $[9,21]$.

A recent systematic review and meta-analysis including 49 studies estimated the overall seroprevalence of SARSCoV-2 antibodies among HCWs was $8.7 \%$ (95\% confidence interval 6.7-10.9\%) with higher seroprevalence detected in North America (12.7\%) compared with Europe (8.5\%), Africa (8.2\%) or Asia (4\%) [8].

The SARS-CoV-2 antibody detection assay we used for the initial screening of our population (Architect ${ }^{\circledR}$ SARSCoV-2 IgG, Abbott, Chicago, IL, USA) has been used in several studies as a screening tool for HCWs and in the general population [22-24]. The same assay has been compared with other antibody detection methods in several studies with good performance characteristics [25-27]. However, when we tested the initially positive results of Abbott Architect ${ }^{\circledR}$ SARS-CoV-2 IgG, with 6 more assays, there was agreement only in one person. For the rest of the personnel,
ECLIA and ELISA methods were negative and there was agreement with some rapid detection assays. In the 6-month follow-up for the only person that all methods gave an initially positive result, the Abbott Architect ${ }^{\circledR}$ SARS-CoV-2 IgG became negative, but the rest remained positive.

In recent publications, that assessed the concordance of the results of different high-throughput automated immunoassays (including our used automated immunoassays), ELISA (included in this study) and RIC (not included) assays, a higher concordance than in our result depending on the used assay was recorded [28] [29].

In areas with low prevalence of SARS-CoV-2 infection $(<15 \%)$, even with antibody detection assays that have high sensitivity and specificity, the positive predictive value is very low (30-50\%)[30]. For this reason, the seroepidemiology results shall be interpreted with caution, as this was the case in our study. Individuals who tested positive in antibody assays, but are not immune could have a false sense of protection, as they could get infected and spread the infection [30]. Antibody tests can be a reliable screening tool in areas with high prevalence of COVID-19. However, as more people are exposed to SARS-CoV-2 worldwide, and the prevalence increases, serological assays could be more reliable in the near future.

The present study has specific limitations that should be taken under consideration for the interpretation of the results. We used only one assay in the initial screening of the population, and only the SARS-CoV-2-positive persons were tested with all 7 antibody assays, so we could not detect possible false-negative results of the initial screening assay. The low incidence of SARS-CoV-2 seropositivity in the total population increases the possibility for false-positive results. 
In addition, there were not serial monthly measurements of antibodies, but only a second time point 6 months after the first, which cannot exclude the possibility of new SARS$\mathrm{CoV}-2$ infection in the meantime. All assays used measured total antibodies and not neutralizing antibody response.

In conclusion, SARS-CoV-2 seroepidemiology studies in areas with low incidence have the possibility of discordant or dubious results. As application of SARS-CoV-2 serologic testing strategies are important to guide public health interventions or individual patient management, better prospective studies are needed to validate and standardize accurate antibody measurement assays, especially rapid diagnostic tests.

Author contributions EP, KB, LZ: performed the initial testing of HCWs. EBT and CD: performed the additional testing of the positive HCWs. AM, LZ, VS: designed and overviewed the study. AM and EBT: wrote the initial manuscript. All authors reviewed and approved the final manuscript.

Funding Not applicable.

Availability of data and material Not applicable.

Code availability Not applicable.

\section{Declarations}

Conflicts of interest All authors declare no competing interests regarding the present study.

Ethical approval The study protocol was approved by the scientific and bioethics committee of "Aghia Sophia” Children's Hospital and was performed in accordance with the ethical standards as laid down in the 1964 Declaration of Helsinki.

Consent to participate Written informed consent was obtained from the participants.

Consent for publication Written informed consent was also obtained for publication.

\section{References}

1. WHO (2020) 'New-type coronavirus causes pneumonia in Wuhan: expert, Xinhua, China'; WHO. Coronavirus diseases (COVID-19), weekly operational update on COVID-19 (2020).

2. Guo YR, Cao QD, Hong ZS, Tan YY, Chen SD, Jin HJ, Tan KS, Wang DY, Yan Y. The origin, transmission and clinical therapies on coronavirus disease 2019 (COVID-19) outbreak - an update on the status. Mil Med Res. 2020;7:11.

3. Wiersinga WJ, Rhodes A, Cheng AC, Peacock SJ, Prescott HC. Pathophysiology, transmission, diagnosis, and treatment of coronavirus disease 2019 (COVID-19): a review. JAMA. 2020;324:782-93.

4. Chu DK, Akl EA, Duda S, Solo K, Yaacoub S, Schunemannauthors C-SURGEs HJ. Physical distancing, face masks, and eye protection to prevent person-to-person transmission of
SARS-CoV-2 and COVID-19: a systematic review and metaanalysis. Lancet. 2020;395:1973-87.

5. De Vito A, Geremia N, Fiore V, Princic E, Babudieri S, Madeddu G. Clinical features, laboratory findings and predictors of death in hospitalized patients with COVID-19 in Sardinia. Italy Eur Rev Med Pharmacol Sci. 2020;24:7861-8.

6. Vaira LA, Hopkins C, Salzano G, Petrocelli M, Melis A, Cucurullo M, Ferrari M, Gagliardini L, Pipolo C, Deiana G, Fiore V, De Vito A, Turra N, Canu S, Maglio A, Serra A, Bussu F, Madeddu G, Babudieri S, Giuseppe Fois A, Pirina P, Salzano FA, De Riu P, Biglioli F, De Riu G. Olfactory and gustatory function impairment in COVID-19 patients: Italian objective multicenterstudy. Head Neck. 2020;42:1560-9.

7. Guarneri C, Rullo EV, Pavone P, Berretta M, Ceccarelli M, Natale A, Nunnari G. Silent COVID-19: what your skin can reveal. Lancet Infect Dis. 2021;21:24-5.

8. Galanis P, Vraka I, Fragkou D, Bilali A, Kaitelidou D. Seroprevalence of SARS-CoV-2 antibodies and associated factors in health care workers: a systematic review and meta-analysis. J Hosp Infect. 2020. https://doi.org/10.1016/j.jhin.2020.11.008.

9. Shields A, Faustini SE, Perez-Toledo M, Jossi S, Aldera E, Allen JD, Al-Taei S, Backhouse C, Bosworth A, Dunbar LA, Ebanks D, Emmanuel B, Garvey M, Gray J, Kidd IM, McGinnell G, McLoughlin DE, Morley G, O’Neill J, Papakonstantinou D, Pickles O, Poxon C, Richter M, Walker EM, Wanigasooriya K, Watanabe Y, Whalley C, Zielinska AE, Crispin M, Wraith DC, Beggs AD, Cunningham AF, Drayson MT, Richter AG. SARS$\mathrm{CoV}-2$ seroprevalence and asymptomatic viral carriage in healthcare workers: a cross-sectional study. Thorax. 2020;75:1089-94.

10. Iversen K, Bundgaard H, Hasselbalch RB, Kristensen JH, Nielsen PB, Pries-Heje M, Knudsen AD, Christensen CE, Fogh K, Norsk JB, Andersen O, Fischer TK, Jensen CAJ, Larsen M, Torp-Pedersen C, Rungby J, Ditlev SB, Hageman I, Mogelvang R, Hother CE, Gybel-Brask M, Sorensen E, Harritshoj L, Folke F, Sten C, Benfield T, Nielsen SD, Ullum H. Risk of COVID-19 in healthcare workers in Denmark: an observational cohort study. Lancet Infect Dis. 2020;20:1401-8.

11. Hueston L, Kok J, Guibone A, McDonald D, Hone G, Goodwin J, Carter I, Basile K, Sandaradura I, Maddocks S, Sintchenko V, Gilroy N, Chen S, Dwyer DE, O'Sullivan MVN. The Antibody Response to SARS-CoV-2 Infection. Open Forum Infect Dis. 2020;7:ofaa387.

12. Gundlapalli AV, Salerno RM, Brooks JT, Averhoff F, Petersen LR, McDonald LC, Iademarco MF, Response CC-. SARS-CoV-2 serologic assay needs for the next phase of the US COVID-19 pandemic response. Open Forum Infect Dis. 2021;8:ofaa555.

13. Yong SEF, Anderson DE, Wei WE, Pang J, Chia WN, Tan CW, Teoh YL, Rajendram P, Toh M, Poh C, Koh VTJ, Lum J, Suhaimi NM, Chia PY, Chen MI, Vasoo S, Ong B, Leo YS, Wang L, Lee VJM. Connecting clusters of COVID-19: an epidemiological and serological investigation. Lancet Infect Dis. 2020;20:809-15.

14. L'Huillier AG, Meyer B, Andrey DO, Arm-Vernez I, Baggio S, Didierlaurent A, Eberhardt CS, Eckerle I, Grasset-Salomon C, Huttner A, Posfay-Barbe KM, Royo IS, Pralong JA, Vuilleumier N, Yerly S, Siegrist CA, Kaiser L, Centre Geneva, for Emerging Viral D, . Antibody persistence in the first six months following SARS-CoV-2 infection among hospital workers: a prospective longitudinal study. Clin Microbiol Infect. 2021;27:784-e1.

15. Houlihan CF, Beale R. The complexities of SARS-CoV-2 serology. Lancet Infect Dis. 2020;20:1350-1.

16. Goldblatt D, Johnson M, Falup-Pecurariu O, Ivaskeviciene I, Spoulou V, Tamm E, Wagner M, Zar HJ, Bleotu L, Ivaskevicius R, Papadatou I, Jogi P, Lischka J, Franckling-Smith Z, Isarova D, Grandjean L, Zavadska D. Cross sectional prevalence of SARS$\mathrm{CoV}-2$ antibodies in health care workers in paediatric facilities in eight Countries. J Hosp Infect. 2021;110:60-6. 
17. Yong G, Yi Y, Tuantuan L, Xiaowu W, Xiuyong L, Ang L, Mingfeng $\mathrm{H}$. Evaluation of the auxiliary diagnostic value of antibody assays for the detection of novel coronavirus (SARS-CoV-2). J Med Virol. 2020;92:1975-9.

18. Dacosta-Urbieta A, Rivero-Calle I, Pardo-Seco J, RedondoCollazo L, Salas A, Gomez-Rial J, Martinon-Torres F. Seroprevalence of SARS-CoV-2 among pediatric healthcare workers in Spain. Front Pediatr. 2020;8:547.

19. Amendola A, Tanzi E, Folgori L, Barcellini L, Bianchi S, Gori M, Cammi G, Albani E, Zuccotti GV. Low seroprevalence of SARSCoV-2 infection among healthcare workers of the largest children hospital in Milan during the pandemic wave. Infect Control Hosp Epidemiol. 2020;41:1468-9.

20. Psichogiou M, Karabinis A, Pavlopoulou ID, Basoulis D, Petsios K, Roussos S, Pratikaki M, Jahaj E, Protopapas K, Leontis K, Rapti V, Kotanidou A, Antoniadou A, Poulakou G, Paraskevis D, Sypsa V, Hatzakis A. Antibodies against SARS-CoV-2 among health care workers in a country with low burden of COVID-19. PLoS One. 2020;15:e0243025.

21. Venugopal U, Jilani N, Rabah S, Shariff MA, Jawed M, Mendez Batres A, Abubacker M, Menon S, Pillai A, Shabarek N, Kasubhai M, Dimitrov V, Menon V. SARS-CoV-2 seroprevalence among health care workers in a New York City hospital: a cross-sectional analysis during the COVID-19 pandemic. Int J Infect Dis. 2021;102:63-9.

22. Stefanelli P, Bella A, Fedele G, Pancheri S, Leone P, Vacca P, Neri A, Carannante A, Fazio C, Benedetti E, Fiore S, Fabiani C, Simmaco M, Santino I, Zuccali MG, Bizzarri G, Magnoni R, Benetollo PP, Merler S, Brusaferro S, Rezza G, Ferro A. Prevalence of SARS-CoV-2 IgG antibodies in an area of northeastern Italy with a high incidence of COVID-19 cases: a population-based study. Clin Microbiol Infect. 2020;27:633-e1.

23. Orner EP, Rodgers MA, Hock K, Tang MS, Taylor R, Gardiner M, Olivo A, Fox A, Prostko J, Cloherty G, Farnsworth CW. Comparison of SARS-CoV-2 IgM and IgG seroconversion profiles among hospitalized patients in two US cities. Diagn Microbiol Infect Dis. 2020;99:115300.

24. Wilkins JT, Gray EL, Wallia A, Hirschhorn LR, Zembower TR, Ho J, Kalume N, Agbo O, Zhu A, Rasmussen-Torvik LJ, Khan SS, Carnethon M, Huffman M, Evans CT. Seroprevalence and correlates of SARS-CoV-2 antibodies in health care workers in Chicago. Open Forum Infect Dis. 2021;8:582.

25. Catry E, Jacqmin H, Dodemont M, Saad Albichr I, Lardinois B, de Fays B, Delaere B, Closset M, Laurent T, Denis O, Galanti L, Mullier F, Huang TD. Analytical and clinical evaluation of four commercial SARS-CoV-2 serological immunoassays in hospitalized patients and ambulatory individuals. J Virol Methods. 2021;289:114060.

26. Harley K, Gunsolus IL. Comparison of the Clinical Performances of the Abbott Alinity IgG, Abbott Architect IgM, and Roche Elecsys Total SARS-CoV-2 Antibody Assays. J Clin Microbiol. 2020;59:e02104-20.

27. Manalac J, Yee J, Calayag K, Nguyen L, Patel PM, Zhou D, Shi RZ. Evaluation of Abbott anti-SARS-CoV-2 CMIA IgG and Euroimmun ELISA IgG/IgA assays in a clinical lab. Clin Chim Acta. 2020;510:687-90.

28. Oakey J, Haslam S, Brown A, Eglin J, Houghton B, Singleton D. Comparison of four high-throughput, automated immunoassays for the detection of SARS-CoV-2 antibodies. Ann Clin Biochem. 2021. https://doi.org/10.1177/00045632211015711. Accessed 2 June 2021.

29. Jones HE, Mulchandani R, Taylor-Phillips S, Ades AE, Shute J, Perry KR, Chandra NL, Brooks T, Charlett A, Hickman M, Oliver I, Kaptoge S, Danesh J, Di Angelantonio E, Wyllie D, Compare study investigators E-Hi. Accuracy of four lateral flow immunoassays for anti SARS-CoV-2 antibodies: a head-to-head comparative study. EBioMedicine. 2021;68:103414.

30. Mathur G, Mathur S. Antibody testing for COVID-19. Am J Clin Pathol. 2020;154:1-3. 